\title{
各種健康茶のラットにおける糖質吸収抑制作用
}

\author{
松浦寿喜, ${ }^{*}, a$ 吉川友佳子, ${ }^{a}$ 升井洋至, ${ }^{a}$ 佐野満昭 ${ }^{b}$
}

\section{Suppression of Glucose Absorption by Various Health Teas in Rats}

\author{
Toshiki MatsuUra, ${ }^{*, a}$ Yukako Yoshikawa, ${ }^{a}$ Hironori Masui, ${ }^{a}$ and Mitsuaki SANO ${ }^{b}$ \\ Department of Food Science and Nutrition, School of Human Environmental Sciences, Mukogawa \\ Women's University, ${ }^{a}$ 6-46 Ikebiraki-cho, Nishinomiya 663-8558, Japan, and \\ School of Pharmaceutical Sciences, University of Shizuoka, ${ }^{b}$ \\ 52-1 Yada, Shizuoka 422-8526, Japan
}

(Received August 8, 2003; Accepted January 29, 2004)

\begin{abstract}
The inhibitory effects on the intestinal digestion and absorption of sugar of health teas that claim beneficial dietary and diabetes-controlling effects were compared in rats using portal cannulae. The measured durations were the times during which the elevation of portal glucose levels resulting from continuous intragastric infusion of sucrose or maltose was suppressed by concentrated teas. The teas investigated included salacia oblonga, mulberry, guava, gymunema, taheebo, yacon, and banaba. The duration of the inhibitory effect on the sucrose load of salacia oblonga, mulberry, and guava were $110 \mathrm{~min}, 20 \mathrm{~min}$, and $10 \mathrm{~min}$, respectively. In contrast, gymunema, taheebo, yacon, and banaba had no significant effect on the continuous infusion of sucrose. These results suggest that there is considerable difference in the efficacy of commercial health teas in influencing glucose absorption.
\end{abstract}

Key words — health tea; portal plasma glucose; rats

\section{緒 言}

緑茶は, 古くから嗜好飲料として飲用されてお り，最近ではカテキン類やフラボノールなど茶に含 まれるポリフェノールの機能性が注目されている. 特に，エピガロカテキンガレート（EGCG）などカ テキン類については, 抗癌作用, ${ }^{1,2)}$ 動脈硬化抑制作 用, ${ }^{3)}$ 血圧上昇抑制作用, ${ }^{4)}$ 抗糖尿病作用, ${ }^{5)}$ 抗肥満 作用6)など様々な疾病予防機能の可能性が報告され ている.このような緑茶の保健効果が注目されたの をきっかけに, 緑茶以外のいわゆる健康茶やその抽 出物も健康食品として市販され，その市場は急成長 を遂げている. 近年の生活習慣病の増加に伴い, 様 々な食品やその成分が健康維持や疾病の予防・改善 をイメージさせる形で健康食品や機能性食品として 販売されている. 特に, 日常最も摂取量の多い糖質 の吸収を抑制することで, 糖尿病や肥満に有効とさ れる健康茶やダイエット茶が数多く市販されている.

サラシアオブロンガ茶は, インド原産のニシキギ

a) 武庫川女子大学生活環境学部, ${ }^{b}$ 静岡県立大学薬学部 e-mail: toshikim@mwu.mukogawa-u.ac.jp
科のツル性樹木の根を原料として製造されたもの で, 糖尿病の予防や肥満予防などに効能を有する健 康茶として市販されている. 桑の葉茶は, 中国の薬 物書で 1596 年に完稿した「本草網目」に記されて いる消渴茶であり, 中国では糖尿病の予防や治療を 目的として用いられていたものである。グァバ茶 は，熱帯や亜熱帯地方に広く自生するフトモモ科バ ンジロウ属の常緑樹から製造されたもので, 食後血 糖值の上昇を抑制するとして, 市販されている. ギ ムネマシルベスタ茶は, インド原産のガガイモ科の 植物で, インドにおいては生薬として糖尿病の治療 に用いられてきたものである. ヤーコンは, 南米ア ンデス高地原産のキク科の多年草草本で, 塊根と塊 茎にはフラクトオリゴ糖が豊富に含まれることか ら, 肥満予防効果や整腸効果が期待されている. バ ナバは, インドネシアやタイなど熱帯, 亜熱帯に分 布するミソハギ科の常緑高木で，フィリピンでは糖 尿病を治療する民間薬として飲用されている. タヒ ボは, 南米アマゾン川流域に生育するノウゼンカズ ラ科の樹木タベブイア・アベラネダエの内部樹皮を 原料にした健康茶で, 癌や糖尿病など多くの疾病に 
効果があるとされている. これらの健康茶は, 入手 のし易さや食品であるという安心感から利用者も多 く, 医薬品と併用して利用されるケースも少なくな い，健康茶は，あくまでも食品であり，医薬品と同 等の効能・効果を期待して利用されるべきものでは ないが，インターネット通販や薬局などでは有効性 の裏付けを持たないまま宣伝, 販売されている例も 見受けられる.

そこで, 本研究では, 健康食品の中でも「糖尿病」 や「肥満予防」に効果があるとされる健康茶の糖質 消化吸収抑制作用について検討した。すすなわち，攝 取エネルギーの約 $60 \%$ が糖質であり，その大部分 が澱粉及び砂糖であることから, 澱粉の加水分解物 であるマルトース及びスクロースを用いて, 各種健 康茶によるこれら糖質の消化吸収抑制作用について 医薬品であるアカルボースと比較し, いわゆる健康 食品と医薬品の有効性の差異を明らかにすることと した.

\section{実 験 方 法}

\section{1. 実験動物 4 週齢の Sprague-Dawley 系雄} 性ラット（Jcl； SD，日本クレア秼）を購入し, 室 温 $23 \pm 1{ }^{\circ} \mathrm{C}$, 湿度 $55 \pm 7 \%$ ，明暗周期 12 時間（明期 $8: 00-20: 00)$ の条件下で飼育した. 固形飼料 （MF；オリエンタル酵母工業株式会社）及び水は 自由に与え, 4 週間予備飼育後 (8 週齡, $264.6 \pm$ $5.1 \mathrm{~g})$ ，実験に供した。

2. 試薬 スクロース, マルトースは, 和光純 薬工業株式会社製の特級品を用いた。健康茶は,

Table 1 に示したものを用いた. すなわち, バナバ 茶, グァバ茶, ギムネマシルベス夕茶, 桑の葉茶 は，オリヒロ株式会社の $100 \%$ 茶葉（焙煎済）を用 いた。 サラシアオブロンガ茶は, 株式会社黒姫和漢 薬研究所の $100 \%$ サラシアオブロンガ根を用いた。 タヒボ茶は, 株式会社アイジェイの $100 \%$ タベブイ ア・アベラネダエ内皮樹皮を用いた。ヤーコン茶 は，農事組合法人ヤーコンさく咲く信州の $100 \%$ ヤーコン葉茎を用いた。対照医薬品として, バイエ ル薬品株式会社製のグルコバイ（1 錠中アカルボー ス $100 \mathrm{mg}$ 含有）を用いた。 血漿中グルコース濃度 の測定には，グルコース測定用キット（グルコース B- テストワコー；和光純薬工業株式会社）を用い た。笑気ガス及び酸素ガスは，ネリキガスより購入
Table 1. Health Tea for Sample

\begin{tabular}{lll}
\hline \hline Name of tea & \multicolumn{1}{c}{ Scientific name } & Country of origin \\
\hline Banaba & Lagerstroemia speciosa & Philippines \\
Guava & Psidium guajava L. & South Africa \\
Gymnema & Gymnema sylvestre & India \\
Mulberry & Morus alba & Japan \\
Salacia & Salacia oblonga & Sri Lanka \\
Taheebo & Tabebuia avellanedae & South America \\
Yacon & Smallantus sonchifolius & South America \\
\hline
\end{tabular}

し, 使用した. フローセンは, 武田薬品工業株式会 社製を用いた。

3. 濃縮茶の調製 各市販健康茶は, 製品のパ ッケージに記載されている方法により熱水抽出し た。すなわち, バナバ茶 $(3 \mathrm{~g})$, グァバ茶 $(8 \mathrm{~g})$, ギムネマシルベス夕茶 $(5 \mathrm{~g})$, 桑の葉茶 $(4 \mathrm{~g})$, サ ラシアオブロンガ茶 $(12 \mathrm{~g})$ 及びタヒボ茶 $(16 \mathrm{~g})$ を熱水 21 で 5 分間煮出し, 抽出液はろ過した後工 バポレーターにより濃縮した。 濃縮残渣に蒸留水を 加え, 全量 $10 \mathrm{ml}$ として 200 倍健康茶濃縮液とし た。なお，マルトース持続投与時には，桑の葉茶及 びグァバ茶 1200 倍濃縮液を用いた。対照薬として は，グルコバイ 1 回投与量（1 錠）を蒸留水に溶解 し, 全量 $10 \mathrm{ml}$ としたグルコバイ水溶液を用いた。

4. 測定方法門脈への門脈血採取用カテーテ ル留置及び胃への試料注入用カテーテルの留置は, 既報7に従って行った（Fig. 1)。すなわち，ラット を笑気・酸素・フローセン (導入期 $2.5 \%$, 維持期 $1.5 \%$ ）混合ガス麻酔下に開腹し，胃に試料注入用 カテーテル（ビニールチューブ : 内径 $0.5 \mathrm{~mm}$, 外 径 $1.0 \mathrm{~mm}$ ), 門脈に採血用カテーテル（ポリエチ レンチューブ：内径 $0.28 \mathrm{~mm}$, 外径 $0.61 \mathrm{~mm}$ ）を 留置した。 これらのカテーテルの他端は, 皮下トン ネルを通して背部に出し, ハーネス及び保護コイル を通し, 試料注入用カテーテルはスイベルに接続し た。胃及び門脈にカテーテルを留置したラットは, 無作為抽出にて 1 群 6 匹ずつ分け, ステンレス製代 謝ケージ内で 24 時間個別に飼育し，この間固形飼 料 MF 及び水は自由に与えた。これらのラットを 16 時間絶食したのち，15\%スクロース水溶液ある いは $15 \%$ マルトース水溶液のいずれかをぺリス ターポンプを用いて $11.25 \mathrm{ml} / \mathrm{kg} / \mathrm{hr}$ の速度で持続 的に投与した。門脈血中グルコース濃度は，持続投 


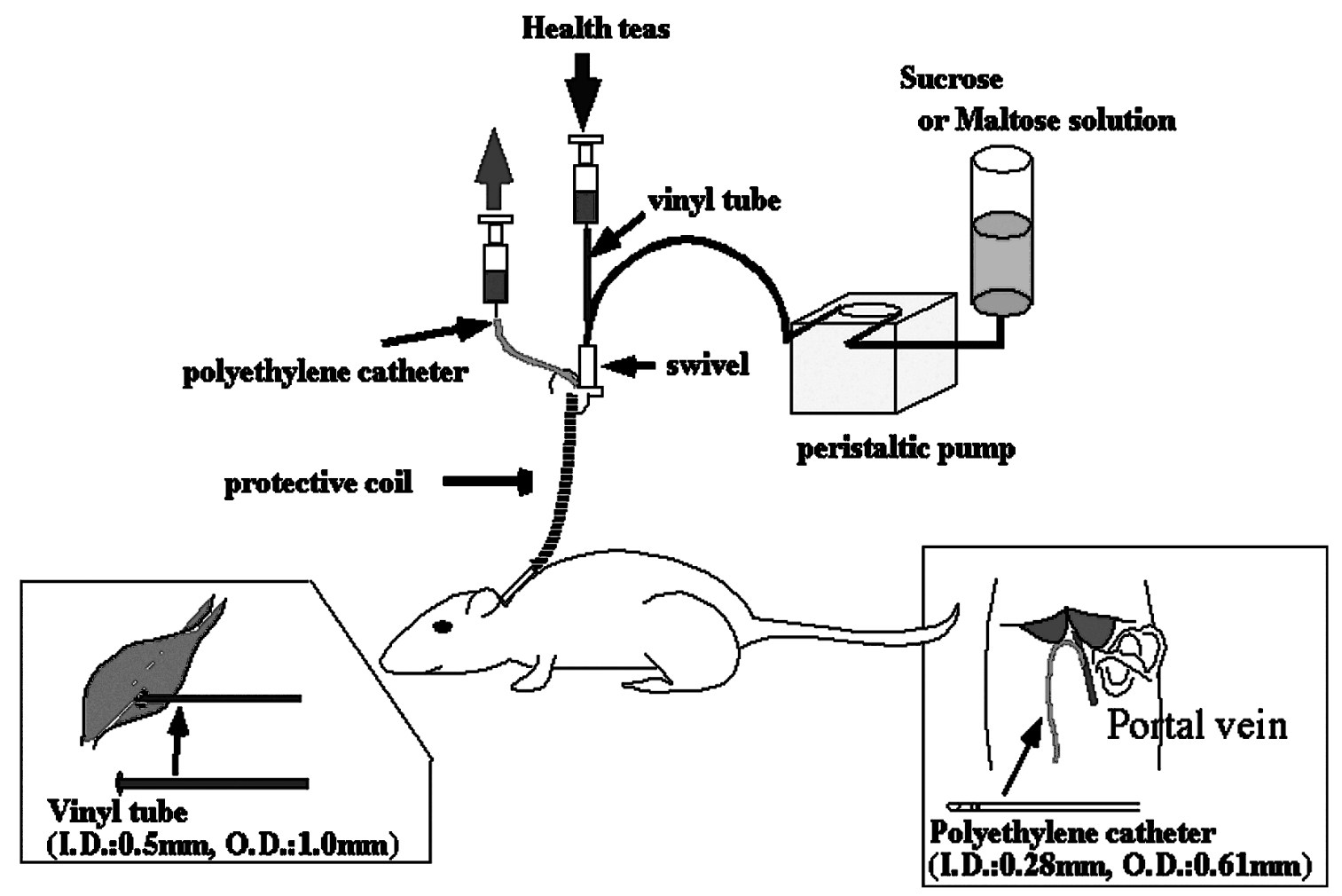

Fig. 1. Technique for the In Vivo Catheterization of the Portal Vein in the Rat

The rats were anesthetized, and the beveled end of a heparin-filled catheter introduced into the portal vein followed by placement for a feeding gastrostomy.

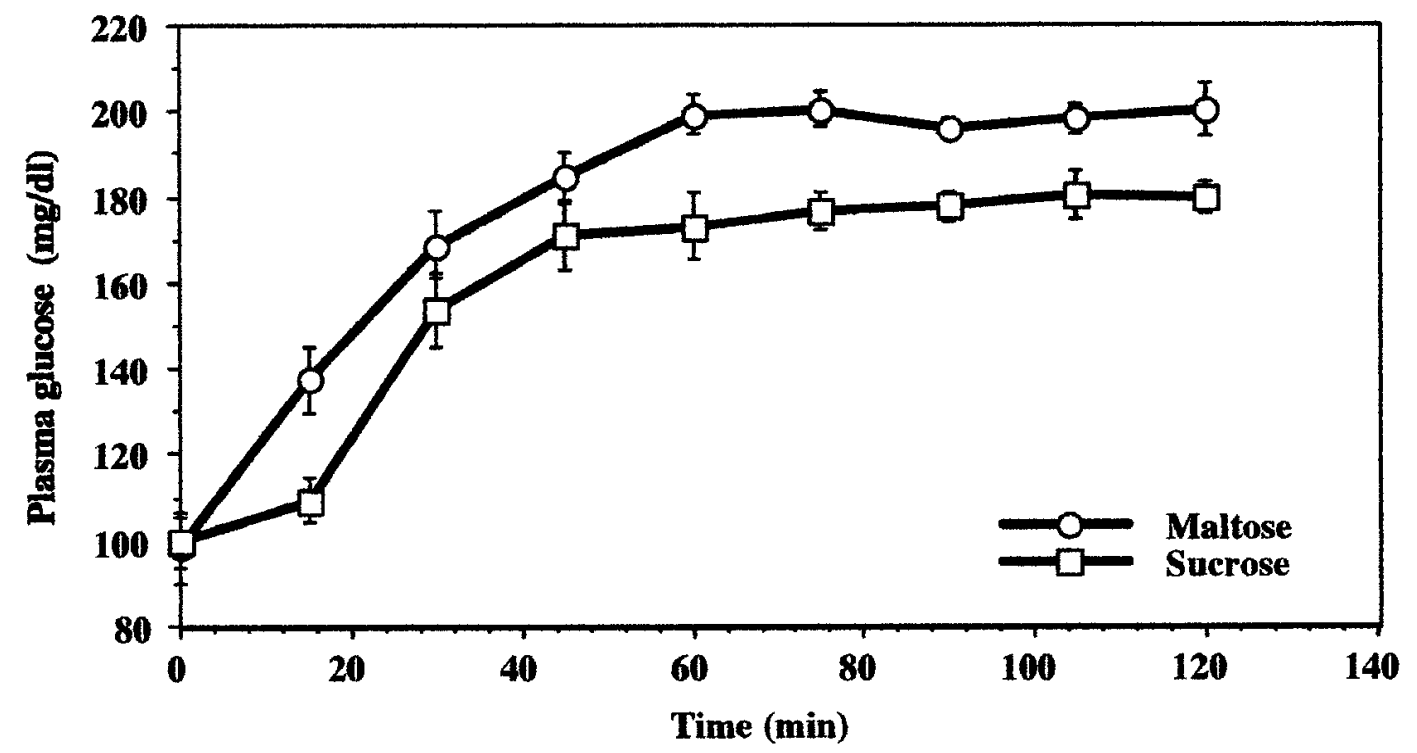

Fig. 2. Changes in Portal Plasma Glucose Concentration during Continuous Administration of Sucrose or Maltose The rats were received continuous intragastric infusion $(11.25 \mathrm{ml} / \mathrm{kg} / \mathrm{hr})$ of a $15 \%$ sucrose solution or a $15 \%$ maltose solution. Each point represents mean \pm S.E.

与開始 60 分以降に一定のレベルで維持されること から (Fig. 2), 持続投与開始後 120 分に各市販健 康茶濃縮液（ $2.4 \mathrm{ml} / \mathrm{kg} ）$ あるいはグルコバイ水溶 液 $(2.4 \mathrm{ml} / \mathrm{kg})$ をそれぞれ試料注入用カテーテル
より胃内投与し，その後 10 分おきに 180 分まで門 脈カテーテルより門脈血 $0.05 \mathrm{ml}$ を採取した。血液 は, 遠心分離して血漿とし, 血漿中グルコース濃度 は, グルコース測定用キット（グルコース B-テス 
トワコー：和光純薬工業株式会社）を用いて測定し た. 阻害作用の持続時間は, 健康茶熱水抽出物投与 後の各時間の門脈血漿中グルコース濃度を投与前の 門脈血墏中グルコース濃度と比較し, 有意差が認め られる時間帯として表示した。なお，動物実験は 「武庫川女子大学動物実験指針」に則つて実施した。

5. 統計処理実験データはすべて平均值士標 準誤差で示した。各種健康茶投与後の各時間帯の門 脈血中グルコース濃度と, 投与前の門脈血グルコー ス濃度群間の有意差検定は, Bonferroni/Dunnの多 重比較検定（Stat View-J5.0）により行った。

\section{実 験 結 果}

1. スクロース持続投与時の血糖上昇抑制作用 $15 \%$ スクロース水溶液を持続投与したラットに各種 健康茶 200 倍濃縮液を投与したときの門脈血漿中グ ルコース濃度の変化を Fig. 3 に示した. 医薬品で あるアカルボース投与時の門脈血漿中グルコース濃 度は，アカルボース投与後 10 分から 120 分まで, 投与前值に比し有意に低值を示し，作用持続時間は 120 分であった。これに対し，健康茶では最も作用 持続時間が長かったのはサラシアオブロンガ茶 200 倍濃縮液で, 投与後 10 分から 110 分まで投与前值 に比し有意に低值を示し，作用持続時間は 110 分で
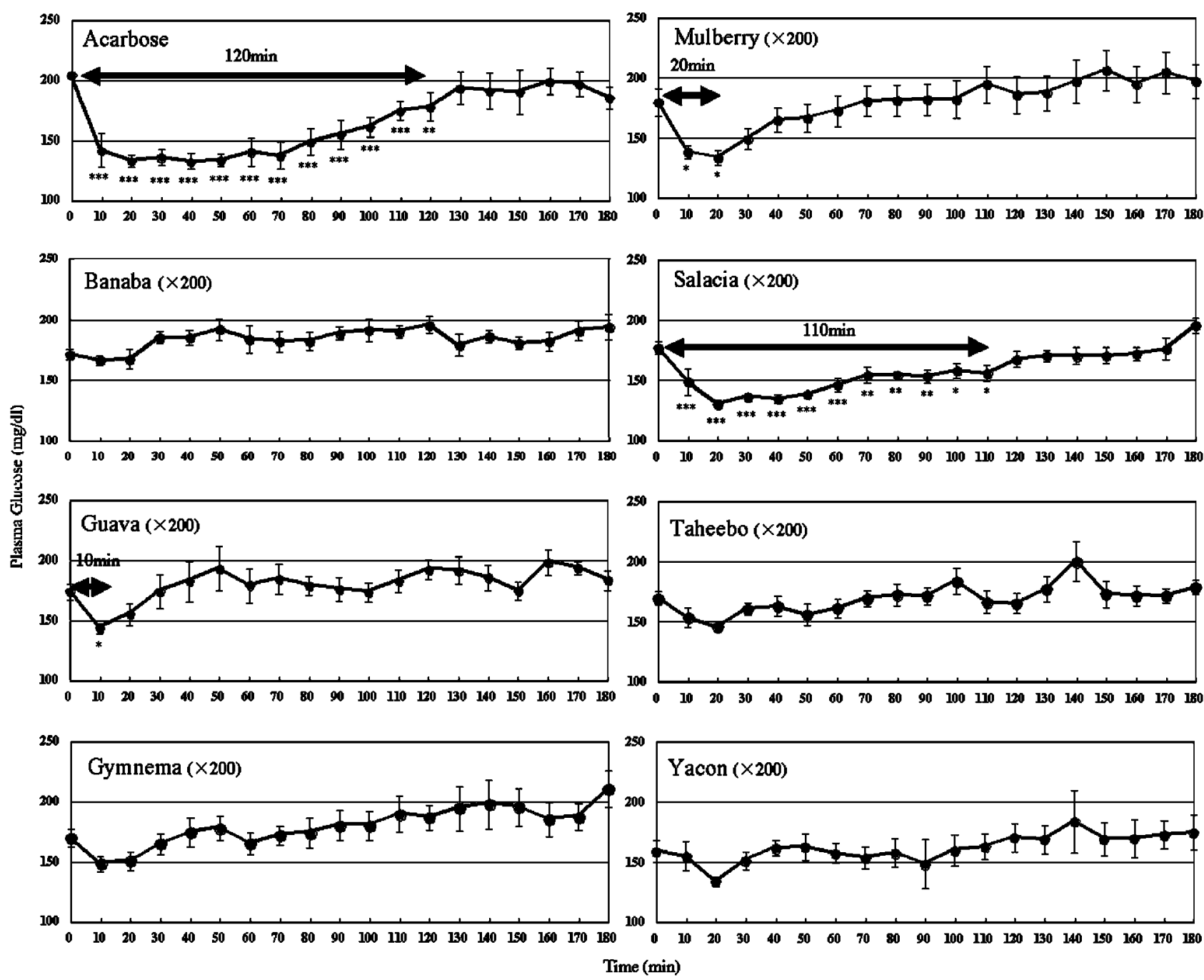

Fig. 3. Changes in Portal Plasma Glucose Concentration after Administration of Health Teas during Continuous Intragastric Infusion of Sucrose

The rats received a continuous intragastric infusion $(11.25 \mathrm{ml} / \mathrm{kg} / \mathrm{hr})$ of $15 \%$ sucrose solution. After the portal plasma glucose concentration reached a plateau level, one of health teas was administered. Each point represents mean \pm S.E. Significant values are indicated by asterisks: ${ }^{*} p<0.05,{ }^{* *} p<0.01$ and ${ }^{* * *} p<0.001$ vs. $0 \mathrm{~min}$ in each group. 
あつた。桑の葉茶及びグァバ茶 200 倍濃縮液の作用 持続時間はそれぞれ 20 分及び 10 分であり，ギムネ マシルベスタ茶, タヒボ茶, バナバ茶及びヤーコン 茶のそれぞれ濃縮液では門脈血漿中グルコース濃度 の有意な低下が認められなかった.

2. マルトース持続投与時の血糖上昇抑制作用 スクロースの持続投与実験で, 血糖上昇抑制作用が 認められたサラシアオブロンガ茶, 桑の葉茶及びグ アバ茶について，さらにマルトース持続投与ラット を用いて，血糖上昇抑制作用を検討した。なお，桑 の葉茶及びグァバ茶についてはパッケージに記載さ れている 6 倍量の茶葉を用いて調製し，使用した。

$15 \%$ マルトース水溶液を持続投与したラットにサ ラシアオブロンガ茶 200 倍濃縮液, 桑の葉 1200 倍 濃縮液及びグァバ茶 1200 倍濃縮液を投与したとき の門脈血漿中グルコース濃度の変化を Fig. 4 に示 した。医薬品であるアカルボース投与時の門脈血漿 中グルコース濃度は, アカルボース投与後 10 分か ら 30 分まで投与前值に比し有意に低值を示し, 作 用持続時間は 30 分であった。これに対し, サラシ アオブロンガ茶 200 倍濃縮液では, 投与後 20 分か ら 30 分まで投与前值に比し有意に低值を示し, 作 用持続時間は 20 分であった。 桑の葉茶 1200 倍濃縮 液の作用持続時間は 110 分, グァバ茶 1200 倍濃縮 液では作用が認められなかった。

\section{考察}

薬局やインターネット通販などで販売されている 健康茶のうち, 糖尿病予防及びダイエットを目的と する説明がなされていた各種健康茶を購入し，パッ ケージに記載されている方法により熱水にて抽出 後, 抽出液を 200 倍あるいは 1200 倍に濃縮し, 最 終容量 $10 \mathrm{ml}$ として実験に供した。対照として用い たアカルボースは, 食後過血糖治療薬として使用さ れている医薬品であり, 健康茶との比較が容易に行 えるよう 1 回投与量である 1 錠 $100 \mathrm{mg}$ を $10 \mathrm{ml}$ の 蒸留水に溶解し, 実験に供した. 対照として用いた アカルボースの投与量については, 作用持続時間が 120 分となる投与量, すなわち $0.024 \mathrm{~g} / \mathrm{kg}(2.4 \mathrm{ml} /$ $\mathrm{kg}$ ）に設定した。健康茶濃縮物は, 健康茶の 21 あ るいは 121 を $10 \mathrm{ml}$ まで濃縮して投与したことか ら, 仮に健康茶濃縮物の作用持続時間が 120 分であ った場合，アカルボース相当量は 21 あるいは 121 と算出できる。 また，作用持続時間が 120 分に満た ない場合は, 作用持続時間が阻害剂の投与量に比例 することを利用し，120 分に達するのに必要とされ る倍率を乗じてアカルボース相当量を算出した.

サラシア属植物の根に含まれている Mangiferin, Salacinol 及び Katalanol などは， $\alpha$-グルコシダー ゼ阻害作用を有することが報告されており, 8 )これ
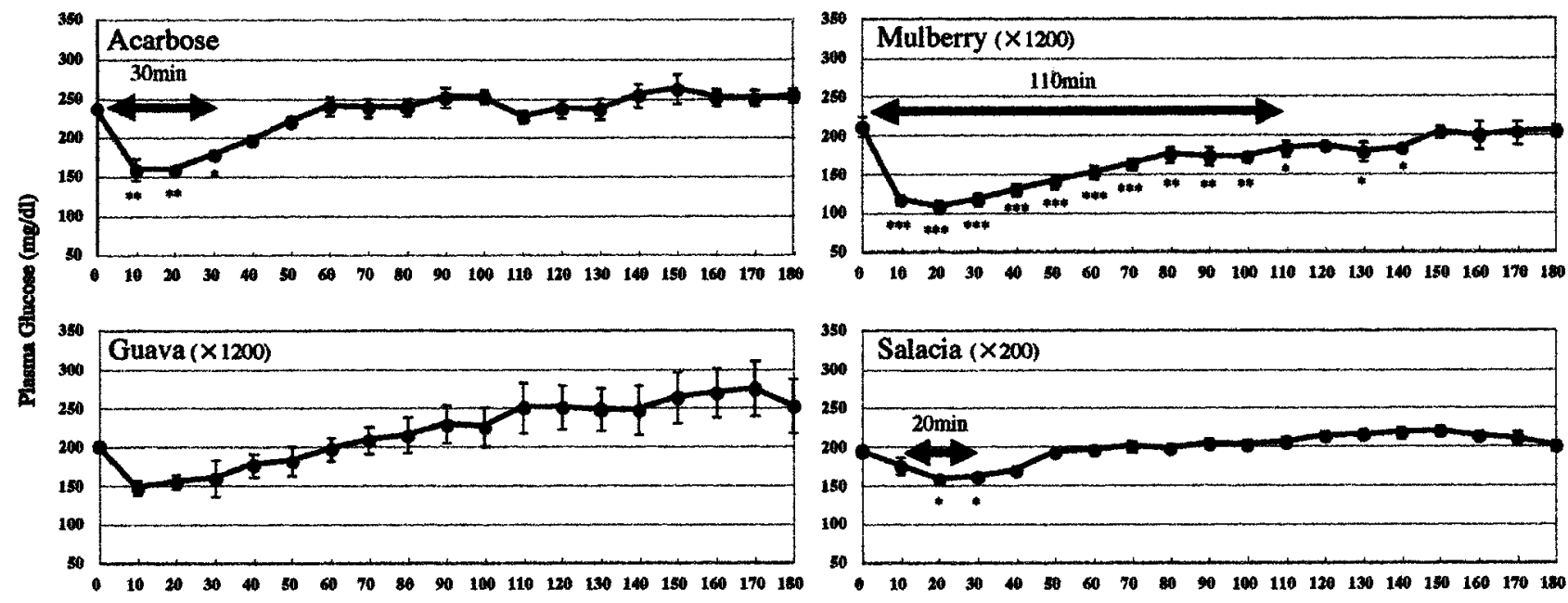

Time (min)

Fig. 4. Changes in Portal Plasma Glucose Concentration after Administration of Health Teas during Continuous Intragastric Infusion of Maltose

The rats received a continuous intragastric infusion $(11.25 \mathrm{ml} / \mathrm{kg} / \mathrm{hr})$ of $15 \%$ maltose solution. After the portal plasma glucose concentration reached a plateau level, one of health teas was administered. Each point represents mean \pm S.E. Significant values are indicated by asterisks : ${ }^{*} p<0.05,{ }^{* *} p<0.01$ and ${ }^{* * *} p<$ 0.001 vs. 0 min in each group. 
らを含む植物の抽出物のヒトやラットにおける血糖 上昇抑制作用, ${ }^{9,10)}$ 糖尿病患者やストレプトゾトシ ン誘発糖尿病ラットにおける血糖低下作用 ${ }^{11)}$ などが 報告されている。 今回の実験では, サラシアオブロ ンガ茶 200 倍濃縮液のスクロースに対する作用持続 時間は 110 分とアカルボースとほぼ同等の阻害作用 を示しており，サラシアオブロンガ茶に含まれるこ れらの物質がスクロースの消化吸収を阻害するもの と考えられた。ただし, 実際の飲用量を推定する と, 作用持続時間は阻害剂の投与量に比例して延長 することから ${ }^{12)}$ サラシアオブロンガ茶でアカル ボースの 1 錠（1 回摂取量）と同等の作用持続時間 を得るためには 1 回 2.21（21×120 分/110 分）の 飲用が必要であると推定された。また，マルトース に対しても同様にアカルボース 1 錠相当量を算出す ると 1 回 $31(21 \times 30$ 分 $/ 20$ 分）の飲用が必要であ ると推定された。

桑の葉抽出物がストレプトゾトシンやアロキサン で誘発した糖尿病マウス及び自然発症糖尿病ラット の血糖值を低下させること, ${ }^{13-17) ~}$ 桑葉に含まれる 1- デオキシノジリマイシンが $\alpha$-グルコシダーゼ阻 害作用を有することも報告されている. ${ }^{18)}$ 今回の研 究では, 桑の葉茶のスクロースに対する作用持続時 間は 20 分であり, アカルボース 1 錠相当量は 121 $(21 \times 120$ 分 $/ 20$ 分）と推定された。さらに, マル トースに対してはスクロースの 6 倍濃度で実験を行 つた結果，作用持続時間は 110 分となったが，アカ ルボース 1 錠相当量に換算すると $3.31 （ 21 \times 6 \times 30$ 分/110 分）と推定された.

グァバ茶については, in vitroにおけるマルター ゼ，スクラーゼ及び $\alpha$-アミラーゼに対する阻害効 果及び糖尿病モデルマウスやヒトにおける有効性が 報告されている。 ${ }^{19)}$ 本研究において, グァバ茶抽出 物のスクロースに対する作用持続時間は 10 分であ り, アカルボース 1 錠相当量は $241(21 \times 120$ 分/ 10 分）と推定された。 また, マルトースでは作用 持続時間は認められず，飲用量は推定できなかった。

ギムネマシルベスタに含まれるギムネマ酸が小腸 におけるグルコースの吸収を抑制し, ${ }^{20)}$ その結果糖 負荷後の血糖上昇を抑制することが報告されてい る. ${ }^{21)}$ 今回の研究では, ギムネマシルベスタ茶にス クロース及びマルトースいずれにおいても吸収抑制 作用は認められなかった。今回用いたラット門脈力
テーテル留置法では， $\alpha$ - グルコシダーゼ活性を阻 害する場合及び糖の輸送担体を阻害する場合のいず れにおいても抑制効果の検出は可能であることか ら，ギムネマシルベスタのグルコース吸収抑制作用 は比較的弱いことが推察された，笠木らは，製茶方 法による血糖上昇抑制作用への影響について検討 し, 番茶タイプ, 煎茶タイプ, 半発酵茶タイプ及び 全発醅茶タイプの 4 種類のギムネマシルベスタ茶の うち, 最も強い作用を有したのは番茶タイプであっ

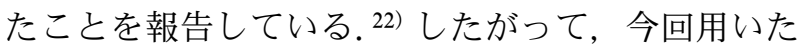
ギムネマシルベスタ茶で血糖上昇抑制作用が認めら れなかったのは，製茶方法の違いによる可能性も考 えられた。

ヤーコンの葉の水抽出物をストレプトゾトシン誘 発糖尿病ラットに 30 日間投与することで, 血糖值 やインスリンレベルを改善することが報告されてい る. ${ }^{23)}$ 今回用いたヤーコン茶は信州で栽培し, 葉と 茎から製造されたものであり, インスリン様物質に よる血糖值の低下が期待される17)が，今回用いたラ ット門脈カテーテル法は腸管からの糖質の消化吸収 のみの評価に限られるため, 作用持続時間は 0 分と なり評価不能であった。

ラットを用いた実験では，バナバ葉抽出物が食後 血糖上昇作用を有することが報告されている. ${ }^{24)}$ 今 回の研究においては有効性は認められなかったが, これは有効成分の作用が腸管における糖質の消化吸 収を抑制するのではなく, 細胞へのグルコースの取 り込み促進 ${ }^{25)}$ な゙によるものであるためと考えられ た.

タヒボは，これに含まれる NFD（ナフト・フラ ン・ディオン） が発癌プロモーション阻害効果を有 するとされるが科学的に証明した論文は見当たらな い。また，糖尿病に対する有効性もあるとされる が，今回の研究ではその有効性は認められておら ず，少なくとも $\alpha$-グルコシダーゼ阻害作用など腸 管における糖質の消化吸収には全く関与していない ものと推察された。

今回の実験では，複数の茶がブレンドされていな い $100 \%$ の健康茶を用いて, 血糖上昇抑制作用の持 続時間を測定したが，その作用は医薬品に比し著し く低いかあるいは全く作用を示さないものも認めら れた。したがって，これらの健康茶は糖尿病のリス クを軽減する効果を有する可能性はあるが，あくま 
でも食品であり，医薬品と同等の効果を期待するも のではないことを十分に認識し, 適切に使用するこ とが大切である。

\section{REFERENCES}

1) Fujita Y., Yamane T., Tanaka M., Kuwata K., Okuzumi J., Takahashi T., Fujiki H., Okuda T., Jpn. J. Cancer Res., 80, 503-505 (1989).

2) Yamane T., Takahashi T., Kuwata K., Oya K., Inagake M., Kitao Y., Suganuma M., Fujiki H., Cancer Res., 55, 2081-2084 (1995).

3) Miura Y., Chiba T., Tomita I., Koizumi H., Miura S., Umegaki K., Hara Y., Ikeda M., Tomita T., J. Nutr., 131, 27-32 (2001).

4) Hara Y., Tono-oka F., J. Jpn. Soc. Nutr. Food Sci., 43, 345-348 (1990).

5) Sakai M., Hara Y., Food Ind. Food Sci. J., 38, 77-82 (1995).

6) Sayama K., Ozeki K., Taguchi M., Oguni I., Biosci. Biotechnol. Biochem., 60, 169-170 (1996).

7) Matsuura T., Shi K., Sakudo T., Habu M., Ichikawa T., Digestion \& Absorption, 19, 5660 (1996).

8) Yoshikawa M., Nishida N., Shimoda H., Takada M., Kawahara Y., Matsuda H., Yakugaku Zasshi, 121, 371-378 (2001) .

9) Shimoda H., Kawamori S., Kawahara Y., J. Jpn. Soc. Nutr. Food Sci., 51, 279-287 (1998).

10) Kajimoto O., Kawamori S., Shimoda H., Kawahara Y., Hirata H., Takahashi T., J. Jpn. Soc. Nutr. Food Sci., 53, 199-205 (2000).

11) Krishnakumar K., Augusti K. T., Vijayammal P. L., Indian J. Physiol. Pharmacol., 43, 510514 (1999).
12) Matsuura T., Ichikawa T., J. Jpn. Soc. Nutr. Food Sci., 50, 363-368 (1997).

13) Chen F., Nakashima N., Kimura I., Kimura M., Yakugaku Zasshi, 115, 476-482 (1995).

14) Kimura M., Chen F., Nakashima N., Kimura I., Asano N., Koya S., J. Trad. Med., 12, 214219 (1995).

15) Nojima H., Kimura I., Chen F., Sugihara Y., Haruno M., Kato A., Asano N., J. Nat. Prod., 61, 397-400 (1998).

16) Lemus I., Garcia R., Delvillar E., Knop G., Phytother. Res., 13, 91-94 (1999).

17) Iizuka Y., Sakurai E., Tanaka Y., Yakugaku Zasshi, 121, 365-369 (2001).

18) Yoshikuni Y., Agric. Biol. Chem., 52, 121128 (1988).

19) Deguchi Y., Osada K., Uchida K., Kimura H., Yoshikawa M., Kudo T., Yasui H., Watanuki M., Nippon Nogeikagaku Kaishi, 72, 923-931 (1998).

20) Shimizu K., Iino A., Nakajima J., Tanaka K., Nakajyo S., Urakawa N., Atsuchi M., Wada T., Yamashita C., J. Vet. Med. Sci., 59, 245251 (1997).

21) Chattopadhyay R.R., J. Ethnopharmacol., 67, 367-372 (1999).

22) Kasagi T., Miyoshi M., Ichikawa O., Ikeda M., J. Yonago Med. Ass., 38, 138-145 (1987).

23) Arbar M. J., Sanchez Riera A. N., Grau A., Sanchez S. S., J. Ethnopharmacol., 74, 125132 (2001).

24) Suzuki Y., Hayashi K., Sakane I., Kakuda T., J. Jpn. Soc. Nutr. Food Sci., 54, 131-137 (2001).

25) Murakami C., Myoga K., Kasai R., Ohtani K., Kurokawa T., Ishibashi S., Dayrit F., Padolina W. G., Yamasaki K., Chem. Pharm. Bull., 41, 2129-2131 (1993). 